eCommons@AKU

January 2011

\title{
Addressing issues of access and fairness in education through dynamic assessment
}

Pauline Rea-Dickins

Aga Khan University, pauline.rea-dickins@aku.edu

Matthew Poehner

Pennsylvania State University, USA

Follow this and additional works at: http://ecommons.aku.edu/eastafrica_ied

Part of the Education Commons

\section{Recommended Citation}

Rea-Dickins, P., Poehner, M. (2011). Addressing issues of access and fairness in education through dynamic assessment. Assessment in Education: Principles, Policy \& Practice, 18(2), 95-97.

Available at: http://ecommons.aku.edu/eastafrica_ied/44 


\title{
Addressing issues of access and fairness in education through Dynamic Assessment
}

\author{
Pauline Rea-Dickins \& Matthew E. Poehner
}

To cite this article: Pauline Rea-Dickins \& Matthew E. Poehner (2011) Addressing issues of access and fairness in education through Dynamic Assessment, Assessment in Education: Principles, Policy \& Practice, 18:2, 95-97

To link to this article: http://dx.doi.org/10.1080/0969594X.2011.567076

曲 Published online: 12 May 2011.

Submit your article to this journal $\pi$

Џll Article views: 866

Q View related articles ¿

4 Citing articles: 1 View citing articles 


\section{EDITORIAL}

\section{Addressing issues of access and fairness in education through Dynamic Assessment}

In his editorial for this journal in 2003, Stobart wrote: 'Assessments come in all shapes and sizes, ranging from international monitoring exercises to work with individual pupils in the classroom' (139). To this we may add that all too often we are powerless to control the ways in which particular assessments are applied or the uses to which assessment data are put, irrespective of the nature of our professional engagement. We do have, nonetheless, an imperative to promote 'assessment as best practice', to educate user communities about the 'limits' of assessment, and to encourage through quality assessment - the fair treatment of individuals and groups. As revealed in Assessment in Education over the years (see for example the review by Broadfoot and Black 2004), we have now achieved better understandings of the consequences from assessments, of the impact of assessment on teaching and of the ways in which student learning may be supported through appropriate teacher mediation. Indeed, one of the major contributions of this journal has been in its disentangling of the constructs that underpin assessment embedded within instruction (e.g. Black and Wiliam 1998; Harlen and James 1997; Sadler 1998; Brookhart, Moss, and Long 2010; Ahmed and Pollitt 2010).

This special issue, 'Addressing issues of access and fairness in education through Dynamic Assessment', seeks to provide an additional lens through which assessment and learning may be systematically explored, the foundations of which derive from the writings of Vygotsky (1987) and were further developed for broader educational implementation from work in the area of special needs diagnosis (e.g., Feuerstein et al. 2003). As argued by Poehner (this issue), dynamic assessment (henceforth DA) provides a coherent, theoretically driven framework for both understanding and supporting learner development. Within DA, we observe two different traditions, one with a more 'measurement + intervention' orientation and the other aligned more closely with pedagogical interactions. This special issue showcases both and also evidences how the dialogic approach to DA shares some of the features of formative assessment (FA), a conceptualisation of assessment that has been widely investigated through the pages of this journal. There is a robust research literature examining applications of DA in the realm of intelligence and general abilities measurement, where it has prompted questions concerning both the nature of such constructs as well as how appropriate intervention programmes may be designed to meet learner needs. These points are reviewed and developed in the contributions to this issue by Kozulin and Tzuriel, respectively. Within the second language (L2) field, where DA has been most vigorously pursued in classroom contexts, it is with the dialogic tradition that FA is more closely aligned. Within the classroom, DA, like certain approaches to FA, is framed as an integrated and iterative process within pedagogical routines. This integration of teaching and assessment as features of L2 DA interactions is apparent in the 
contributions to this issue from Ableeva and Lantolf, Siekmann and Charles, and Poehner and van Compernolle. Both FA and DA are concerned with promoting student learning and the roles of the teacher in this process, but one characterisation that differentiates FA from DA is that the latter is presented as a specific cohesive theory of development, with the result that support is highly systematic, whereas the former is more eclectic and draws on a range of concepts to explain the construct and to drive practice. We also see evidence of FA from a policy perspective in this issue, in the Country Profile by Berry concerning assessment trends in Hong Kong. Against an enduring backdrop of high-stakes testing, she shows how, over the last 10-15 years, the Hong Kong government has been working to change the assessment climate and, since 2000, has introduced curriculum reform in which the concept of a 'curriculum, pedagogy and assessment cycle' is firmly embedded (Curriculum Development Council 2009, cited in Berry this issue, 206). This reform is accompanied by the expectation of changes in practice in local schools with the implementation of assessment pedagogies that support the learning process (see also Hamp-Lyons and Tavares, forthcoming 2011). Central to both FA and DA, however, is a view of assessment as social practice, with a focus on the 'learner-as-individual', which contrasts with the ever-prevailing embodiment of assessment as a technological and 'objective' undertaking, which in the absence of balanced assessment opportunities may come at a highly significant cost - social, personal, justice and fairness, economic - for our learners.

This special issue first provides a conceptual mapping of Vygotsky's theory and the leading lines of DA research it has generated. Then, through a series of studies, each of these strands is both represented and extended through contributions from both veteran DA researchers as well as scholars whose work takes DA in new directions. Two central themes emerge in the interests of fairness to the individual - that of providing systematic opportunities for learners to demonstrate how much they know and can do with mediation rather than readily accepting that they do not know and therefore 'don't make the cut' and, in particular, the potential of DA in systematically engaging learners in the activity of their own development. As Broadfoot and Black wrote: 'assessment can be a powerful force in supporting learning, and a mechanism for individual empowerment' $(2004,23)$.

\section{References}

Ahmed, A., and A. Pollitt. 2010. The support model for interactive assessment. Assessment in Education: Principles, Policy \& Practice 17, no. 2: 133-67.

Black, P., and D. Wiliam. 1998. Assessment and classroom learning. Assessment in Education: Principles, Policy \& Practice 5, no. 1: 7-74.

Broadfoot, P., and P. Black. 2004. Redefining assessment? The first ten years of Assessment in Education. Assessment in Education: Principles, Policy \& Practice 11, no. 1: 7-26.

Brookhart, S.M., C.M. Moss, and B.A. Long. 2010. Teacher enquiry into formative assessment practices in remedial reading classrooms. Assessment in Education: Principles, Policy \& Practice 17, no. 1: 41-58.

Feuerstein, R., L. Falik, Y. Rand, and R.S. Feuerstein. 2003. Dynamic assessment of cognitive modifiability. Jerusalem: ICELP Press.

Hamp-Lyons, L., and N. Tavares. Forthcoming 2011. Interactive assessment - a dialogic and collaborative approach to assessing learners' oral language. In Classroom-based language assessment, ed. D. Tsagari and I. Csepes. Frankfurt: Peter Lang.

Harlen, W., and M. James. 1997. Assessment and learning: Differences and relationships between formative and summative assessment. Assessment in Education: Principles, Policy \& Practice 4, no. 3: 365-79. 
Sadler, R. 1998. Formative assessment: Revisiting the territory. Assessment in Education: Principles, Policy \& Practice 5, no. 1: 77-84.

Stobart, G. 2003. Editorial: The impact of assessment: Intended and unintended consequences. Assessment in Education: Principles, Policy \& Practice 10, no. 2: 139-40.

Vygotsky, L.S. 1987. Thinking and speech. In the collected works of L.S. Vygotsky. Vol. 1. Problems of general psychology, ed. R.W. Rieber and A.S. Carton, 39-285. New York: Plenum.

Pauline Rea-Dickins

Aga Khan University Institute for Educational Development, East Africa,

Tanzania

Matthew E. Poehner Department of Curriculum and Instruction, Pennsylvania State University, University Park, PA, USA 